\title{
Histone H2B Type 1-B
}

National Cancer Institute

\section{Source}

National Cancer Institute. Histone H2B Type 1-B. NCI Thesaurus. Code C162923.

Histone H2B type 1-B (126 aa, $\sim 14 \mathrm{kDa}$ ) is encoded by the human H2BC3 gene. This protein plays a role in the regulation of DNA wrapping. 